\title{
ANALISIS RASIO KEUANGAN UNTUK MENGUKUR KINERJA KEUANGAN PADA PT. GAS NEGARA TBK PERIODE 2013-2017 (Berdasarkan Keputusan Menteri BUMN Nomor: KEP-100/MBU/2002)
}

\author{
Amthy Suraya $^{1)} \&$ Shella Meylani ${ }^{2)}$
}

1,2) dosen dan mahasiwa universitas pamulang, email : dosen00627@unpam.ac.id

\section{ARTICLES}

INFORMATION

ABSTRACT

\section{JURNAL SEKURITAS \\ (Saham, Ekonomi, Keuangan dan Investasi ) \\ Vol.2, No.3, Mei 2019 \\ Halaman : $101-116$ \\ C LPPM \& Prodi Manajemen \\ UNVERSITAS PAMULANG \\ ISSN (online) : 2581-2777 \\ ISSN (print) : :2581-2696}

Keyword :

Return On Asset, Current Ratio, Debt to Equity Ratio, Growth

JEL. classification : C33, G20, G23, N65

\section{Contact Author :}

PRODI MANAJEMEN UNPAM

JL.Surya Kencana No.1 Pamulang

Tangerang Selatan - Banten

Telp. (021) 7412566, Fax (021) 7412491 Email :

jurnalfinance.unpam@gmail.com
Penilaian tingkat keuangan suatu perusahaan dapat dilakukan dengan menganalisis laporan keuangan perusahaan. Untuk mengetahui apakah keadaan keuangan perusahaan dalam kondisi yang baik dapat dilakukan berbagai analisa, salah satunya adalah analisa rasio. Tujuan penelitian ini adalah untuk mengetahui kinerja keuangan pada PT. Gas Negara Tbk ditinjau dari analisa rasio keuangan.

Metode analisa yang digunakan adalah analisis deskriptif dan kuantitatif menggunakan rasio likuiditas, profitabilitas, aktivitas dan solvabilitas. Data dan informasi penelitian di peroleh dari Bursa Efek Indonesia dan Web PT. Gas Negara Tbk.

Berdasarkan rasio likuiditas rata rata Current Ratio perusahaan adalah 255\% dan Cash Ratio adalah 171\% berdasarkan Keputusan Menteri BUMN No: KEP-100/MBU/2002 bahwa PT. Gas Negara Tbk dalam indikator Current Ratio dan Cash Ratio memperoleh nilai diatas rata rata dan rasio likuiditas perusahaan dikatakan sehat. Rata rata profitabilitas perusahaan, ROE $25 \%$, ROI $346 \%$ bahwa PT. Gas Negara Tbk dalam indikator ROE dan $\mathrm{ROI}$ memperoleh nilai diatas rata rata dan rasio profitabilitas perusahaan dikatakan sehat. Rata rata aktivitas perusahaan seperti Collection Periods 26 hari, Perputaran Persediaan 34 hari, dan TATO $166 \%$ bahwa PT. Gas Negara Tbk dalam indikator Collection Periods, Perputaran Persediaan dan TATO memperoleh nilai diatas rata rata dan rasio aktvitas perusahaan dikatakan sehat. Rasio solvabilitas rata rata Total Sendiri Terhadap Total Asset atau (TMS Terhadap TA) yaitu 162\% dalam indikator TMS Terhadap TA pada PT Gas Negara, Tbk. memperoleh nilai diatas rata rata berdasarkan Keputusan Menteri BUMN No: KEP-100/MBU/2002. Dari uraian diatas dapat disimpulkan bahwa kinerja keuangan perusahaan sehat. 


\section{A. Pendahuluan}

Dewasa ini dunia usaha sudah semakin berkembang, pada umumnya suatu perusahaan didirikan dengan tujuan untuk memperoleh laba. Laba merupakan hasil yang menguntungkan atas usaha yang di lakukan oleh perusahaan pada suatu periode tertentu. Dengan adanya laba ini perusahaan dapat menggunakan sebagai tambahan pembiayaan dalam menjalankan usahanya, dan yg terpenting sebagai alat untuk menjaga keberlangsungan hidup suatu perusahaan.

Banyaknya para pelaku dalam dunia bisnis mengakibatkan tingkat persaingan antar perusahaan akan menjadi semakin ketat. Persaingan pada perusahaan akan berpengaruh positif yaitu untuk mendorong perusahaan selalu meningkatkan mutu dan kualitas produk yang dihasilkan, tetapi persaingan juga akan menimbulkan dampak negatif bagi perusahaan yang gagal dalam meningkatkan mutu dan kualitas produkproduknya yang akan menyebabkan perusahaan kalah bersaing dalam meraih pasar.

Kinerja keuangan dan manajemen yg baik, dalam suatu perusahaan juga memerlukan analisis terhadap laporan keuangan untuk mengetahui kemampuan perusahaan dalam mengatasi masalah-masalah keuangan perusahaan serta mengambil keputusan yg tepat dan cepat. Melalui analisis laporan keuangan, manajemen dapat mengetahui posisi keuangan, kinerja keuangan dan kekeuatan (Financial Strength) yang di miliki perusahaan. Selanin berguna bagi perusahaan dan manajemenya, analisis laporan keuangan juga di perlukan oleh pihak-pihak yg berkepentingan lain seperti investor dan pemerintah untuk menilai kondisi keuangan perusahaan dan perkembangan dari perusahaan tersebut.

"Rasio Keuangan merupakan salah satu alat analisis bagi keuangan untuk menilai kinerja suatu perusahaan berdasarkan perbandingan data keuangan yg terdapat pada pos laporan keuangan seperti neraca dan laporan laba rugi" (Fahmi Irham, 2010). Analisis rasio yg dapat digunakan sebagai bahan pertimbangan bagi investor untuk membuat keputusan atau pertimbangan tentang pencapaian perusahaan dan proyek di masa yg akan datang.

PT.Gas Negara (PERSERO) Tbk. merupakan sebuah Perusahaan milik Negara yang dirintis sejak tahun 1859, ketika masih bernama Firma L.I. Enthoven \& Co Gravenhage. Pada tanggal 13 Mei 1965, berdasarkan Peraturan Pemerintah No. 19/1965, perusahaan ditetapkan sebagai Perusahaan Gas Negara (PGN). Kemudian, peraturan Pemerintah No. 2 Tahun 1984, Perseroan berubah status hukumnya dari Perusahaan Umum ("Perum"). Setelah itu, diubah menjadi Perseroan Terbatas yang dimiliki oleh Negara berdasarkan Peraturan Pemerintah No. 3 tahun 1994 Akta Pendirian Perusahaan No. 48 tanggal 30 Mei 1996 yang dikatakan oleh notaris Adam Kasdarmaji, S.H. Seiring dengan perubahan status Perseroan menjadi Perusahaan terbuka. Perusahaan Gas Negara adalah perusahaan nasional Indonesia terbesar di bidang transportasi dan distribusi gas bumi yg berperan besar dalam pemenuhan gas bumi domestik. Saham PGN dicatatkan di Bursa Efek Jakarta dan Bursa Efek Surabaya pada 15 Desember 2003.

Berdasarkan data uraian diatas, maka dalam ini peneliti tertarik untuk melakukan penelitian dan menganalisis rasio keuangan yang terdapat pada PT. Gas Negara Tbk. Sehingga dalam penyusunan laporan akhir ini peneliti memilih utnuk menggunakan judul "ANALISIS RASIO KEUANGAN UNTUK MENGUKUR KINERJA KEUANGAN PADA PT. GAS NEGARA TBK BERDASARKAN KEPUTUSAN MENTERI BUMN NO: KEP. 100/MBU/2002". 


\section{B. Rumusan Masalah}

1. Bagaimana Rasio Likuiditas pada PT Gas Negara Tbk. selama periode tahun 2013 2017 ?

2. Bagaimana Rasio Profitabilitas pada PT. Gas Negara Tbk. selama periode tahun $2013-2017$ ?

3. Bagaimana Rasio Akitivitas pada PT. Gas Negara Tbk. selama periode tahun 2013 2017 ?

4. Bagaimana Rasio Solvabilitas pada PT. Gas Negara Tbk. selama periode tahun 2013 -2017 ?

5. Bagaimana kinerja keuangan yg di analisis dengan menggunakan rasio likuiditas rasio profitabilitas rasio aktivitas dan rasio solvabilitas berdasarkan Keputusan Menteri BUMN No: KEP-100/MBU/2002 pada PT. Gas Negara Tbk. selama periode tahun $2013-2017$ ?

\section{Kerangka Berfikir}

Kerangka berfikir adalah ringkasan atau gambaran dalam tujuan pustaka atas dasar teori teori yang menjadi landasan dalam penelitian yang di lakukan oleh penulis. Semua prosedur yang akan di tuangkan dalam skripsi telah peneliti tulis secara jelas dan dirangkai dalam kerangka pemikiran.

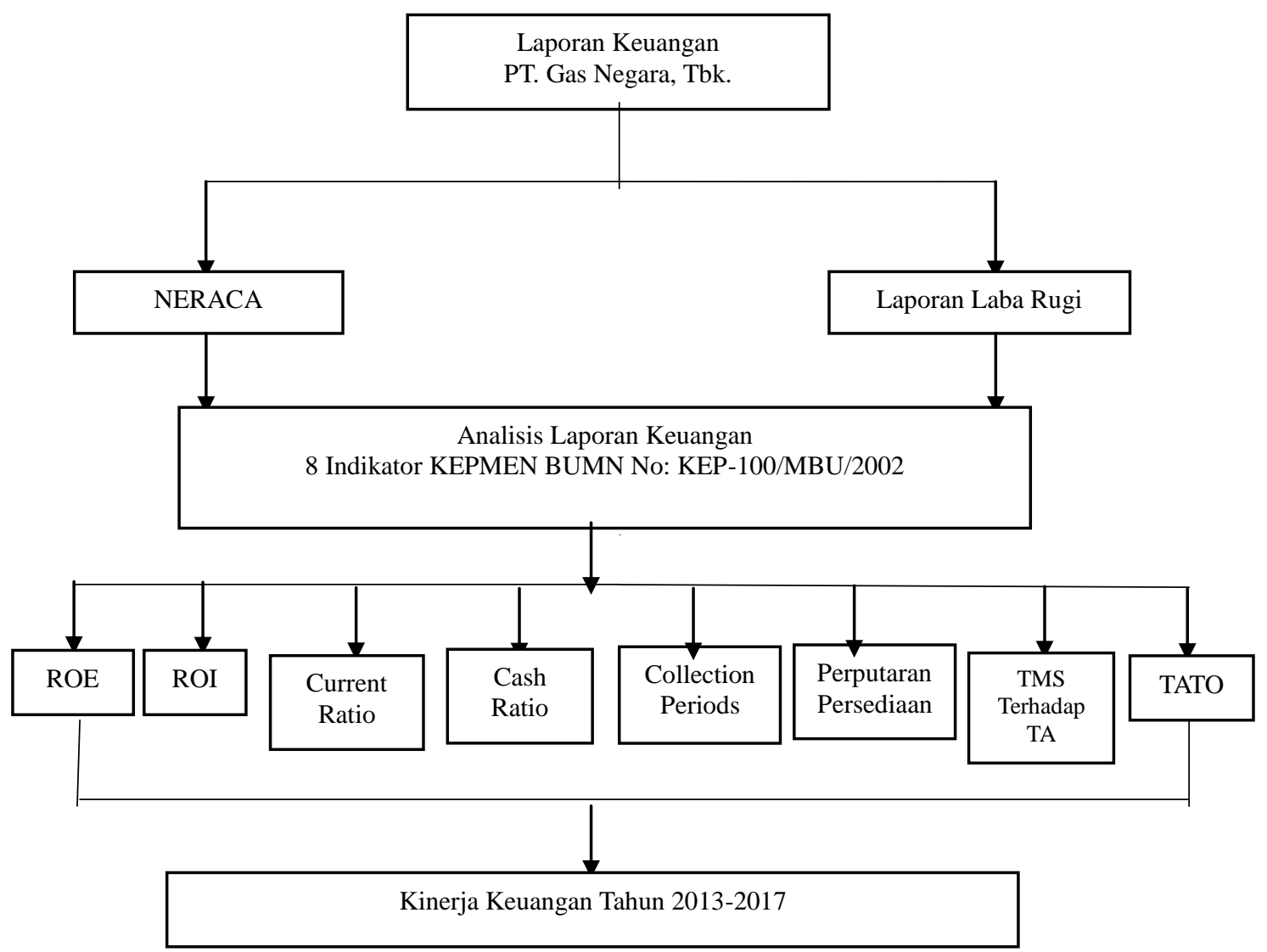




\section{Tinjauan Pustaka}

\section{Analisis Laporan Keuangan}

Salah satu tugas penting manajemen atau investor setelah akhir tahun ialah menganalisis laporan keuangan perusahaan. Analisis ini didasarkan pada laporan keuangan yang sudah disusun. Sebaiknya laporan keuangan itu adalah laporan yang diyakini kewajarannya.

Meurut sofyan syafri Harap (2015:190) "analisis laporan keuangan adalag menguraikan pos-pos laporan keuangan menjadi unit informasi yang lebih kecil dan melihat hubungan yang bersifat signifikan atau yang mempunyai makna antara satu dengan yang lain antara data kuantitatif maupun data non-kuantitatif dengan tujuan untuk mengetahui kondisi keuangan lebih dalam yang sangat penting dalam proses menghasilkan keputusan yang tepat".

\section{Rasio Likuiditas}

Menurut Arief Sugiono dan Edy Untung (2016:57) "Rasio Likuiditas bertujuan untuk mengukur kemampuan perusahaan dalam memenuhi kewajiban jangka pendeknya".

Jenis - jenis rasio likuiditas yang dapat digunakan perusahaan untuk mengukur kemampuan perusahaan dalam memenuhi kewajiban jangka pendeknya berdasarkan Keputusan Menteri BUMN No: KEP-100/MBU/2002, yaitu:

a. Rasio Lancar (Current Ratio)

"Rasio lancar merupakan rasio yang menunjukan sejauh mana aktiva lancar menutupi kewajiban - kewajiban lancarnya. Semakin besar perbandingan aktiva lancar dengan utang lancar semakin tinggi kemampuan perusahaan menutupi kewajiban jangka pendeknya" (Harahap 2010:132).

Adapun rumus Rasio Lancar (Current Ratio) berdasarkan Keputusan Menteri BUMN No: KEP-100/MBU/2002 adalah sebagai berikut:

$$
\text { Current Ratio }=\frac{\text { Current Asset }}{\text { Current Liabilities }} \times 100 \%
$$

b. Rasio Kas (Cash Ratio)

"Merupakan alat yang digunakan untuk mengukur seberapa besar uang kas yang tersedia untuk membayar utang. Ketersediaan uuang kas dapat ditujukan dari tersedianya dana kas atau yang setara dengan kas seperti rekening giro atau tabungan yang ada di bank. Data dikatakan rasio ini menunjukan kemampuan sesungguhnya bagi perusahaan untuk membayar utang-utang jangka pendek". (Harahap 2010:122).

Adapun rumus Rasio Kas (Cash Ratio) berdasarkan Keputusan Menteri BUMN No: KEP-100/MBU/2002 adalah sebagai berikut:

$$
\text { Cash Ratio }=\frac{\text { Kas+Surat Berharga Jangka Pendek }}{\text { Current Liabilities }} \times 100 \%
$$

\section{Rasio Profitabilitas}

Menurut Agus Sartono (2010:122) 'Profitabilitas adalah kemampuan perusahaan memperoleh laba dalam hubunganta dengan penjualan, total aktiva maupun modal sendiri". 
Dalam praktiknya, jenis-jenis rasio profitabilitas yang dapat digunakan berdasarkan Keputusan Menteri BUMN No: KEP-100/MBU/2002 adalah:

a. Return On Equity (ROE)

Makin tinggi rasio ini, makin baik artinya posisi pemilik perusahaan makin kuat, demikian pula sebaliknya.

Adapun rumus untuk mencari Return On Equity (ROE) berdasarkan Keputusan Menteri BUMN No: KEP-100-MBU/2002 adalah sebagai berikut:

$$
\mathrm{ROE}=\frac{\text { Laba setelah pajak }}{\text { Modal Sendiri }} \times 100 \%
$$

b. Return On Investment (ROI)

Hasil pengembalian investasi atau lebih dikenal dengan nama Return on Investment (ROI) merupakan rasio yang menunjukkan hasil (Return) atas jumlah aktiva yang digunakan dalam perusahaan. $\mathrm{ROI}$ juga merupakan suatu ukuran tentang efektivitas manajemen daam mengelola investasinya.

Adapun rumus untuk mencari Return On Invesment (ROI) berdasarkan Keputusan Menteri BUMN No: KEP-100/MBU/2002 adalah sebagai berikut :

$$
\mathrm{ROI}=\frac{\text { EBIT }+ \text { Penyusutan }}{\text { Capital Employed }} \times 100 \%
$$

\section{Rasio Aktivitas}

"Merupakan rasio yang digunakan untuk mengukur efektivitas perusahaan dalam menggunakan aktiva yang dimilikinya. Atau dapat pula dikatakan rasio ini digunakan untuk mengukur tingkat efisiensi pemanfaatan sumber daya perusahaan. Rasio aktivitas juga digunakan untuk menilai kemmpuan perusahaan dalam melaksanakan aktivitas sehari - hari”.(Kasmir 2013:145)

Dirangkum dalam praktiknya, jenis-jenis rasio Aktivitas yang dapat digunakan berdasarkan Keputusan Menteri BUMN No: KEP-100/MBU/2002 adalah:

a. Collection Periods

"Perputaran piutang meruapakan rasio yang digunakan untuk mengukur berapa lama penagihan piutang selama satu periode atau berapa kali dana yang tertanam dalam piutang ini berputar dalam satu periode". (Kasmir, 2012:176)

Dalam praktiknya Collection Periods menggunakan rumus berdasarkan Keputusan Menteri BUMN No: KEP-100/MBU/2002 sebagai berikut :

$$
\mathrm{CP}=\frac{\text { Total Piutang Usaha }}{\text { Total Pendapatan Usaha }} \times 365 \text { hari }
$$

b. Perputaran Persediaan

"Persediaan di definisikan sebagai barang jadi yang disimpan atau digunakan untuk dijual pada periode mendatang, yang dapat berbentuk bahan baku yang disimpan untuk di proses, barang dalam proses mafaktur dan barang jadi yang disimpan untuk dijual maupun diproses". Ikatan Akuntan Indonesia (2009:142).

Dalam praktiknya Perputaran Persediaan menggunakan rumus berdasarkan Keputusan Menteri BUMN No: KEP-100/MBU/2002 sebagai berikut :

$$
\mathrm{PP}=\frac{\text { Total Persediaan }}{\text { Total Pendapatan Usaha }} \times 365 \text { hari }
$$

c. Total Asset Turn Over (TATO) 
"Rasio ini melihat sejauh mana keseluruhan set yang dimiliki oleh perusahaan terjadi perputaran secara efektif” Fahmi (2012:135).

Dalam praktiknya Total Asset Turn Over (TATO) menggunakan rumus berdasarkan Keputusan Menteri BUMN No: KEP-100/MBU/2002 sebagai berikut :

$$
\text { TATO }=\frac{\text { Total Pendapatan }}{\text { Capital Employed }} \times 100 \%
$$

\section{Rasio Solvabilitas}

Rasio Solvabilitas atau Leverage Ratio, merupakan rasio yang digunakan untuk mengukur sejauh mana aktiva perusahaan dibiayai dengan utang. Artinya. Seberapa besar beban utang yang ditanggung perushaan dibandingkan aktivanya. Dalam arti luas dikatakan bahwa rasio solvablitas digunakan untuk mengukur kemampuan perusahaan utnuk membayar seluruh kewajiban baik jangka pendek maupun jangka panjang apabila perusahaan dibubarkan. Yang dapat digunakan berdasarkan Keputusan Menteri BUMN No: KEP-100/MBU/2002 adalah:

a. Total Modal sendiri Terhadap Total Asset ( TMS Terhadap TA)

Rasio TMS bermanfaat untuk mengukur sumber pembiayaan utang sebagai pembiayaan yang berbiaya tetap.

Dalam praktiknya Total Asset Turn Over (TATO) menggunakan rumus menurut Keputusan Menteri BUMN No: KEP-100/MBU/2002 sebagai berikut :

$$
\text { TMS Terhadap TA }=\frac{\text { Total Modal Sendiri }}{\text { Total Asset }} \times 100 \%
$$

\section{Kinerja Keuangan}

Menurut Irham Fahmi (2011:142) "kinerja keuangan adalah salah suatu analisis yang dilakukan untuk melihat sejauh mana suatu perusahaan telah melaksanakan dengan menggunakan aturan-aturan pelaksanaan keuangan secara baik dan benar". Seperti dengan membuat suatu laporan keuangan yang telah memenuhi standard an ketentuan dalam SAK (Standar Akuntansi Keuangan) atau GAP (General Acepted Accounting Principle) dan lainnya, secara umum "kinerja keuangan dapat didefinisikan sebagai prestasi kinerja yang dapat didefinisikan sebagai prestasi kinerja yang dapat dicapai oleh suatu perusahaan selama jangka waktu tertentu". Prestasi yang dimaksud adalah efektifitas operasional perusahaan baik dilihat dari segi ekonomi maupun manajemennya. Untuk mengetahui prestasi yang berhasil dicapai oleh perusahaan, maka kita harus menilai kinerjanya.

Menurut Sugiyono (2009:65) dari segi manajemen keuangan, perusahaan dikatakan mampunyai kinerja keuangan yang baik atau tidak, dapat diukur dengan:

1. Kemampuan perusahaan untuk memenuhi kewajiban (utang) yang akan jatuh tempo (liquidity).

2. Kemampuan perusahaan untuk menyusun stuktur pendanaan, yaitu perbandingan antara utang dan modal (leverage).

3. Kemampuan perusahaan untuk memperoleh keuntungan (profitability).

4. Kemampuan perusahaan untuk berkembang growth), dan

5. Kemampuan perusahaan untuk mengelola asset secara maksimal (activity). 


\section{E. Metedologi Penelitian}

\section{Ruang Lingkup Penelitian}

Penelitian ini dilakukan pada PT. Gas Negara Tbk. dengan alamat di JL. K.H. Zainul Arifin No. 20 Jakarta 11140 Indonesia.

Penelitian ini dilakukan pada Bulan Januari sampai bulan Maret 2015. Data yang diambil adalah data laporan keuangan untuk periode 2013 sampai 2017.

\section{Unit Analisis}

Unit analisis dalam penelitian adalah laporan keuangan PT. Gas Negara Tbk berupa laoran laba rugi dan neraca dari tahun 2013 sampai 2017.

\section{Sumber dan Jenis Data Penlitian}

Sumber data yang diolah lebih lanjut menjadi bentuk-bentuk seperti tabel, grafik, diagram dan sebagainya. Sehingga lebih informatif oleh pihak lain. Umar (2011:84)

Sumber data yang dikumpulkan dalam penyusuanan sekripsi ini diperoleh dari data sekunder yang diambil dari PT. Gas Negara Tbk. Data yg digunakan terdiri dari: Data yang dimaksud adalah data berupa sejarah PT. Gas Negara Tbk tahun 2013-2017.

Menurut Sugiyono (2012:7) yaitu data yang berupa angka-angka. Yang di maksud adalah data laporan keuangan berupa laporan berupa laporan nercara dan laporan laba rugi PT. Gas Negara Tbk.

\section{Metode Pengumpulan Data}

1. Dokumentasi

Pengumpulan data dan informasi yang diperoleh dari dokumen-dokumen perusahaan.

2. Studi Kepustakaan

Pengumpulan data yang diperoleh dari kepustkaan, seperti artikal, buku, laporan keuangan dan internet.

\section{Metode Analisis Data}

Dalam penelitian ini, metode ini digunakan oleh peneliti menggunakan mengolah data sekunder yang sudah ada kebenaranya dan setelah itu di olah berdsarakan Keputusan Menteri BUMN No: KEP-100/MBU/2002. Rumus data yang digunakan penulis dalam menyusun penelitian ini adalah analisis rasio likuiditas analisis rasio profitabilitas rasio aktvitas dan analisis solbvabilitas menurut KEP-100/MBU/2002

\section{F. Hasil Penelitian dan Pembahasan}

\section{Gambaran Umum Perusahaan}

Perusahaan Gas Negara (PGN) adalah perusahaan nasional Indonesia terbesar dibidang transportasi dan distribusi gas bumi yang berperan besar dalam pemenuhan gas bumi domestik. PGN terus memperkuat pondasi dan bertransmormasi dari perusahaan transmisi dan distribusi gas bumi menjadi penyedia solusi energi terintegrasi, yang mendorong pemanfaatan gas bumi untuk kebutuhan masyarakat dan industri.

Resmi menjadi Perusahaan Gas Negara pada 13 Mei 1965, kiprah PGN telah dimulai sejak era kolonial. Banyak hal terjadi selama dari satu setengah abad PGN telah mengarungi sejarah pajang industri gas di Indonesia. 
Pada tahun 1859 - 1965 didirikan perusahaan swasta Belanda, Firma L.J.N. Eindhoven \& CO Gravenhage. PGN baru ditetapkan sebagai perusahaan negara pada 13 Mei 1965

Pada tahun 1994 - 1998 Perluasan bisnis dan ekspansi PGN di ikuti pembentukan anak usaha PT Transportasi Gas Indonesia

Pada tahun 2003 saham PGN dicatatkan di Bursa Efek Jakarta dan Bursa Efek Surabaya dengan kode PGAS pada 15 Desember 2003

Pada tahun 2007 - 2012 Pembentukan anak usaha PT. PGAS Telekomunikasi Nusantara, PT PGAS Solution, PT Saka Energi Indonesia dan PT PGN LNG Indonesia.

Pada tahun 2016 PGN memulai pembangunan dan pengelolaan proyek jaringan jasa bumi rumah tangga di wilayah Batam, Surabaya dan Tarakan, setelah sebelumnya ditahun 2015 ditugaskan mengelola jaringan di 11 wilayah. PGN melakukan transformasi organisasi bersama Anak dan Afliasi dalam bentuk ONE PGN mengukuhkan langkah ke tahapan selanjutnya menuju perusahaan kelas dunia di bidang gas.

Berdasarkan perusahaan pemerintah No.19/1965 Perusahaan Gas Negara (PGN) menjadi badan hukum yang berhak untuk melakukan usahanya secara mandiri dengan ruang lingkup usaha penyediaan tenaga gas dan industri gas, terutama untuk meningkatkan derajat kehidupan masyarakat umum.

\section{a. Visi}

Menjadi solusi terdepan berstandar Internasional dalam pemanfaatan gas dan pemenuhan energi yang berkedaulatan.

\section{b. Misi}

Meningkatkan nilai tambah Perusahaan bagi stakeholders melalui:

- Penguatan bisnis inti di bidang transportasi, niaga gas bumi

- Pengembangan usaha pengolahan gas

- Pengembangan usaha jasa operasi, pemeliharaan dan keteknikan yang berkaitan dengan industri migas

- Profitisasi sumber daya dan aset Perusahaan dengan mengembangkan usaha lainnya.

\section{Analisis Data dan Hasil Pembahasan}

TABEL DAFTAR INDIKATOR DAN BOBOT ASPEK KEUANGAN

\begin{tabular}{|l|c|}
\hline \multicolumn{1}{|c|}{ Indikator } & Bobot dalam Non Infrastruktur \\
\hline 1. Imbalan Kepada Pemegang Saham (ROE) & 20 \\
\hline 2. Imbalan Investasi (ROI) & 15 \\
\hline 3. Rasio Kas (Cash Ratio) & 5 \\
\hline 4. Rasio Lancar (Current Ratio) & 5 \\
\hline 5. Collection Periods (CP) & 5 \\
\hline 6. Perputaran Persediaan (PP) & 5 \\
\hline 7. Perputaran Total Asset & 10 \\
\hline $\begin{array}{l}\text { 8. Rasio Modal Sendiri Terhadap Total Aktiva } \\
\text { (TMS Terhadap TA) }\end{array}$ & $\mathbf{7 0}$ \\
\hline Total Bobot & \\
\hline
\end{tabular}


Tabel 4.6

Perhiungan ROE

Periode 2013-2017

\begin{tabular}{|l|c|c|l|l|c|}
\hline Tahum & $\begin{array}{c}\text { EAT } \\
(1)\end{array}$ & $\begin{array}{c}\text { Modal Sendin } \\
(2)\end{array}$ & $\begin{array}{c}\text { ROF }= \\
(1):(2) \times 100\end{array}$ & Skor & Bobot Non \\
Infastruktur
\end{tabular}

Swmber: Keputuran Menteri (BUMN) No: KEP-100/MBU/2002 (data diolah)

\section{ROE}

\section{$50 \%$}

$40 \%$

$30 \%$

$20 \%$

$10 \%$

$0 \%$

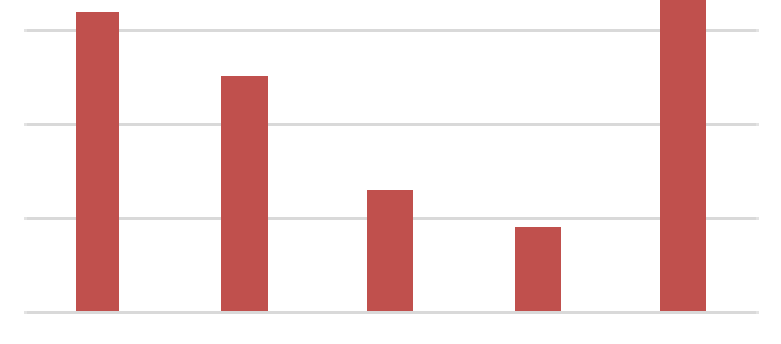

\section{7}

Berdasarkan gambar diatas ROE PT. Gas Negara, Tbk tertinggi terjadi pada tahun 2017 yaitu sebesar 46\% dan ROE terendah PT. Gas Negara, Tbk pada tahun2016 hanya sebesar $9 \%$. 


\section{Tabel}

Perhiungan $R O I$

Periode 2013-2017

\begin{tabular}{|c|c|c|c|c|c|}
\hline Tabun & $\begin{array}{l}\text { EBIT + } \\
\text { Penyusutan (1) }\end{array}$ & $\begin{array}{l}\text { Capital Employed } \\
\text { (2) }\end{array}$ & $\begin{array}{l}\text { ROI }= \\
(1):(2) x \\
100\end{array}$ & Skor & $\begin{array}{l}\text { Bobot Non } \\
\text { Infrastruktur }\end{array}$ \\
\hline 2013 & 1.125 .081 .669 & 1.780 .527 .848 & 6396 & 15 & \multirow{5}{*}{15} \\
\hline 2014 & 978.765 .428 & 1.860 .815 .321 & 5296 & 15 & \\
\hline 2015 & 437.364 .583 & 1.722 .530 .837 & 2506 & 15 & \\
\hline 2016 & 384.985 .146 & 2.124 .674 .229 & 1896 & 15 & \\
\hline 2017 & 275.550 .022 & 1.808 .047 .993 & $150 \%$ & 15 & \\
\hline
\end{tabular}

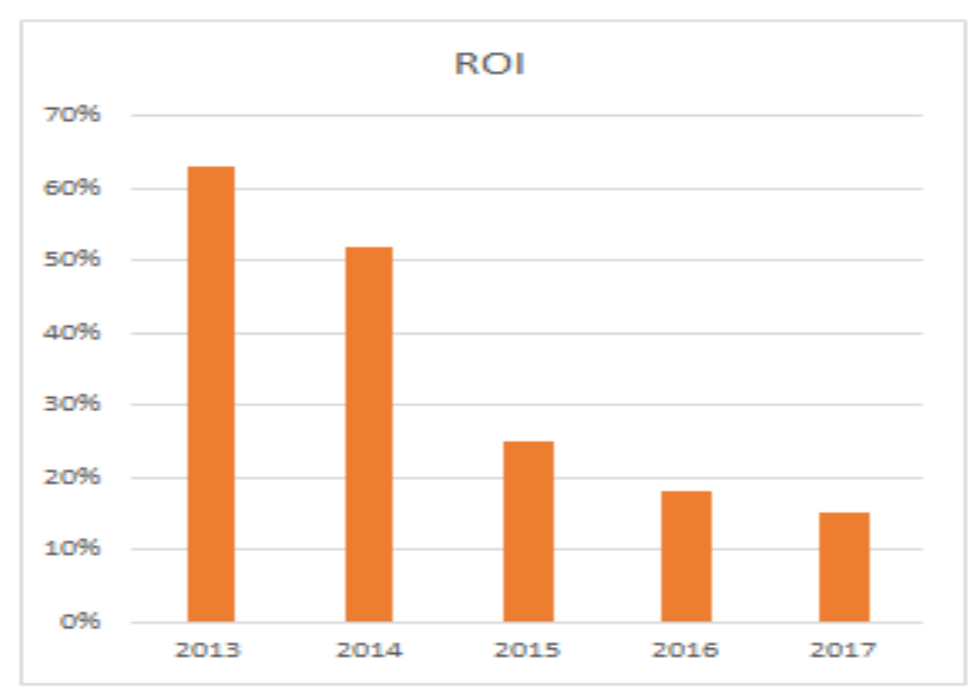

Berdasarkan gambar diatas ROI PT. Gas Negara, Tbk tertinggi terjadi pada tahun 2013 yaitu sebesar 63\% dan ROI terendah PT. Gas Negara, Tbk pada tahun 2017 yaitu sebesar $15 \%$.

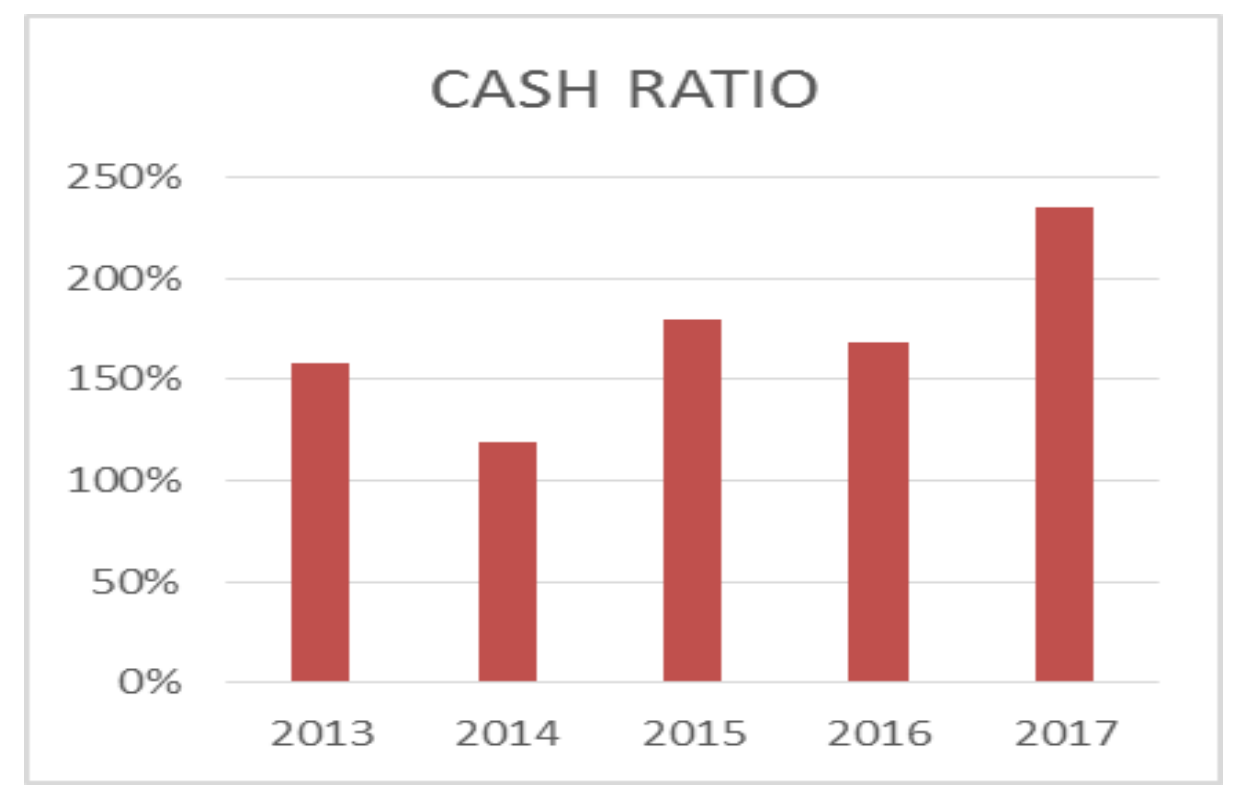


Berdasarkan gambar diatas Cash Ratio PT. Gas Negara, Tbk tertinggi terjadi pada tahun 2017 yaitu sebesar 235\% dan Cash Ratio terendah PT. Gas Negara, Tbk pada tahun 2014 yaitu sebesar 119\%.

Tabel 4.3

Perhiungan Current Ratio (Rasio Lancar)

Periode 2013 - 2017

\begin{tabular}{|c|c|c|c|c|c|}
\hline Tahun & $\begin{array}{c}\text { Aktiva L ancar } \\
\text { (1) }\end{array}$ & $\begin{array}{c}\text { Utang } \\
\text { Lancar/Current } \\
\text { Liabilities } \\
\text { (1) }\end{array}$ & $\begin{array}{c}\text { Current } \\
\text { Ratio= (1) } \\
:(2) \times 100\end{array}$ & Skor & $\begin{array}{l}\text { Bobot Non } \\
\text { Infrastuktur }\end{array}$ \\
\hline 2013 & 1.780 .527 .848 & 885.798 .906 & $201 \%$ & 5 & \multirow{5}{*}{5} \\
\hline 2014 & 1.860 .815 .321 & 1.090 .616 .756 & $170 \%$ & 5 & \\
\hline 2015 & 1.722 .530 .837 & $667,320.181$ & $258 \%$ & 5 & \\
\hline 2016 & 2.124 .674 .229 & 815.371 .887 & $260 \%$ & 5 & \\
\hline 2017 & 1.808 .047 .993 & 466.661 .068 & $387 \%$ & 5 & \\
\hline
\end{tabular}

Swmber:Keputusan Menteri (BUMN) No: KEP-100/MBU/2002 (data diolah)

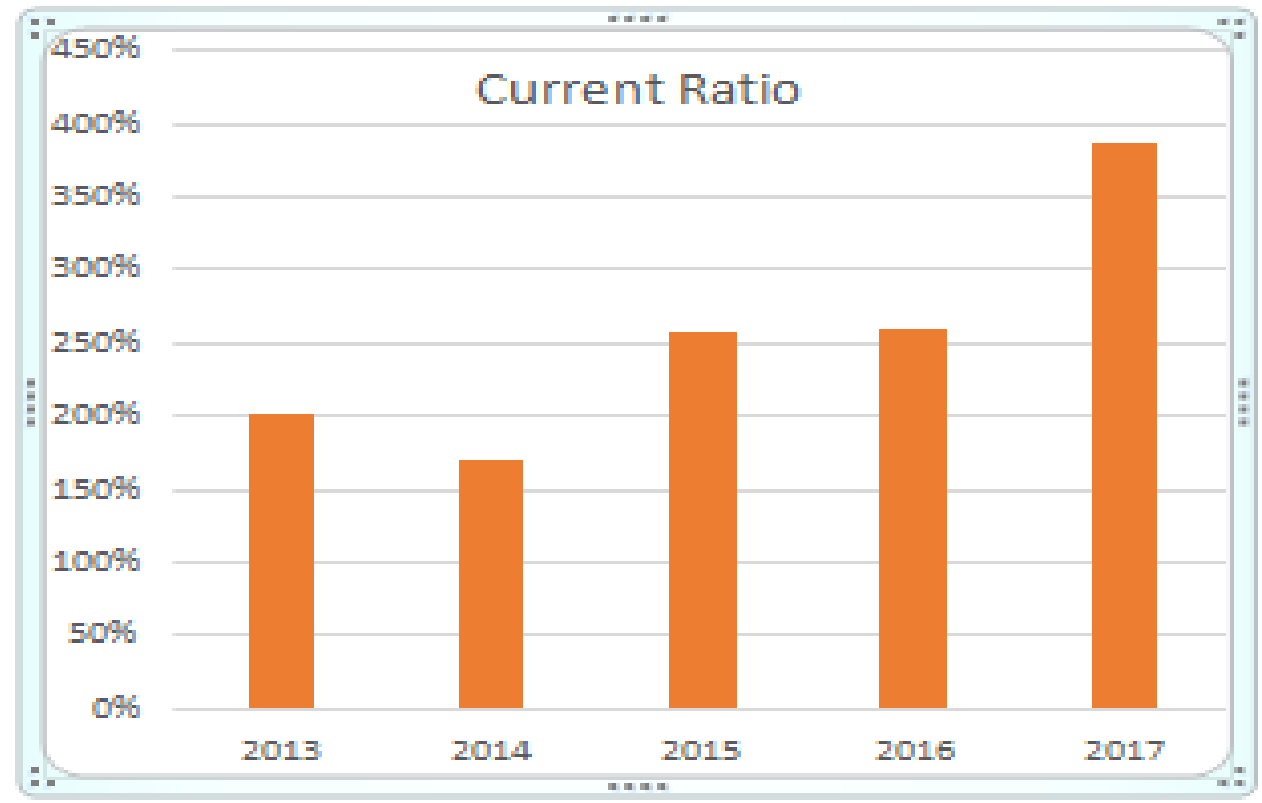

Berdasarkan gambar diatas Current Ratio PT. Gas Negara, Tbk tertinggi terjadi pada tahun 2017 yaitu sebesar 387\% dan Current Ratio terendah PT. Gas Negara, Tbk pada tahun 2014 yaitu sebesar $170 \%$.

Berdasarkan gambar diatas Collection Periods PT. Gas Negara, Tbk mengalami kenaikan selama 3 (tiga) tahun kali berturut - turut yaitu 34 hari dan Collection Periods terendah PT. Gas Negara, Tbk pada tahun 2016 yaitu 13 hari. 
Tabel 4.8

\section{Perhiungan Perputaran Persediaan}

Periode 2013-2017

\begin{tabular}{|c|c|c|c|c|c|}
\hline Tabun & $\begin{array}{l}\text { Total } \\
\text { Persediaan } \\
\text { (1) }\end{array}$ & $\begin{array}{l}\text { Total } \\
\text { Pendapatan } \\
\text { Usaba (2) }\end{array}$ & $\begin{array}{l}\text { Perputaran } \\
\text { Persediaan }= \\
\text { (1): (2) } \times 365\end{array}$ & Skor & $\begin{array}{l}\text { Bobot Non } \\
\text { Infrastrulktur }\end{array}$ \\
\hline 2013 & 14.615 .268 & 3.001 .516 .630 & 177 hari & 3 & \multirow{5}{*}{5} \\
\hline 2014 & 65.367 .426 & 3.408 .590 .061 & 69 hari & 4,5 & \\
\hline 2015 & 43.453 .022 & 3.068 .790 .845 & 51 hari & 4,5 & \\
\hline 2016 & 65.293 .227 & 2.934 .778 .710 & 81 hari & 4 & \\
\hline 2017 & 60.820 .710 & 2.969 .591 .811 & 74 hari & 4,5 & \\
\hline
\end{tabular}

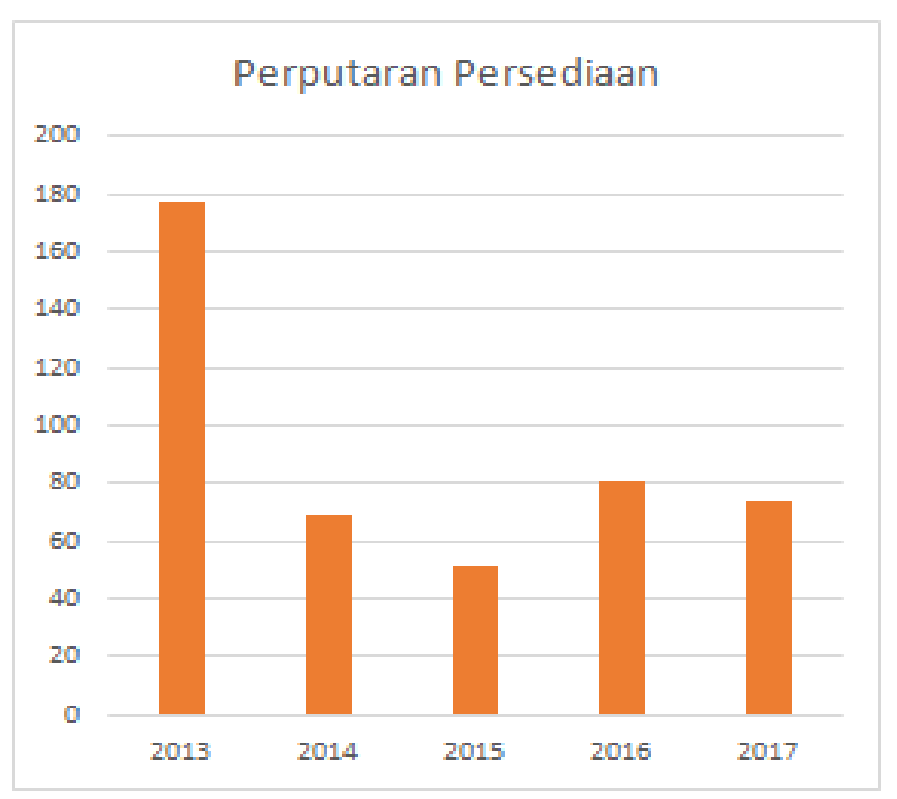

Berdasarkan gambar diatas Perputaran Persediaan PT. Gas Negara, Tbk mengalami kenaikan pada tahun 2013 yaitu 177 hari dan Perputaran Persediaan terendah PT. Gas Negara, Tbk pada tahun 2015 hanya diperlukan 51 hari.

Berdasarkan gambar diatas TATO PT. Gas Negara, Tbk tertinggi terjadi pada tahun 2014 yaitu sebesar 183\% dan TATO terendah PT. Gas Negara, Tbk pada tahun 2016 yaitu sebesar $138 \%$. 
Tabel 4.10

(Perhiungan TMS Terhadap TA)

Periode 2013-2017

\begin{tabular}{|l|l|l|l|l|l|}
\hline Tahun & $\begin{array}{l}\text { Total Modal } \\
\text { Sendiri (1) }\end{array}$ & Total Asset (2) & $\begin{array}{l}\text { TMS } \\
\text { Terhad ap } \\
\text { TA (1): (2) x } \\
100\end{array}$ & Skor & $\begin{array}{l}\text { Bobot Non } \\
\text { Infrastruktur }\end{array}$ \\
\hline 2013 & 3.727 .226 .523 & 1.780 .527 .848 & $153 \%$ & 6,5 & \multirow{2}{*}{10} \\
\hline 2014 & 2.963 .069 .775 & 860.815 .321 & $1590 \%$ & 6,5 & \\
\hline 2015 & 3.022 .804 .054 & 1.722 .530 .837 & $1750 \%$ & 6,5 \\
\hline 2016 & 3.170 .193 .334 & 2.124 .674 .229 & $149 \%$ & 6,5 \\
\hline 2017 & 3.186 .912 .879 & 1.808 .047 .993 & $176 \%$ & 6,5 & \\
\hline
\end{tabular}

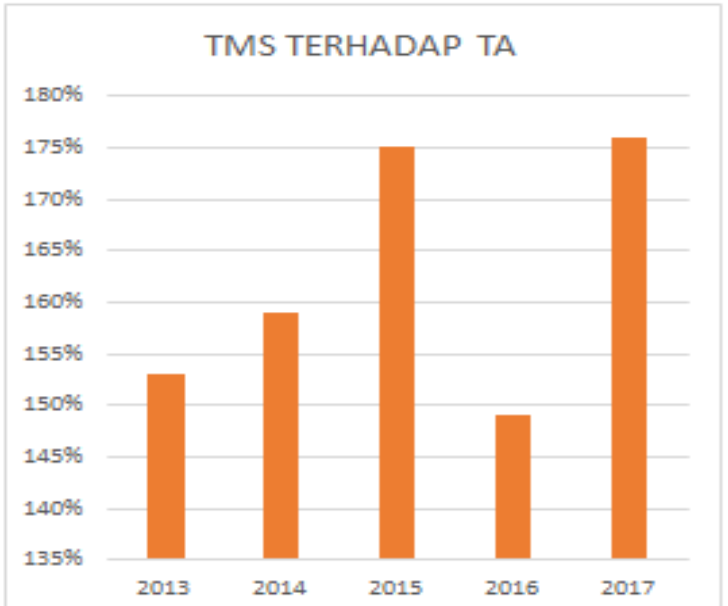

Berdasarkan gambar diatas TMS Terhadap TA PT. Gas Negara, Tbk tertinggi terjadi pada tahun 2017 yaitu sebesar 176\% dan TMS Terhadap TA terendah PT. Gas Negara, Tbk pada tahun 2016 yaitu sebesar 149\%.

Berdasarkan hasil penelitian yang dilakukan pada PT. Gas Negara, Tbk dari tahun 2013 sampai dengan 2017, untuk menilai tingkat kesehatan keuangan maka menurut Sutrisno (2007:34) bobot dari hasil peilaian aspek keuangan dibuat ekuivalenya agar dapat diperoleh hasil akhir kategori kesehatan BUMN. Bobot dari hasil penilaian aspek keuangan akan dikalikan dengan $70 \%$. Hasil total skor PT. Gas Negara, Tbk dari tahun 2013 sampai dengan 2017 setelah dikalikan dengan ekuivalenya kemudian dinilai dengan kategori tingkat kesehatan disajikan pada Tabel di bawah ini:

Tabel Penilaian Tingkat Kesehatan Keuangan PT. Gas Negara, Tbk Berdasarkan SK Menteri BUMN No: KEP-1 00/MBU/2002 :

\begin{tabular}{|c|c|c|c|c|c|c|}
\hline Tabun & $\begin{array}{l}\text { Total Skor } \\
\text { (1) }\end{array}$ & $\begin{array}{l}\text { Bobot } \\
\text { (2) }\end{array}$ & $\begin{array}{l}\text { Total Bobot } \\
(1)=\frac{(L)}{100}\end{array}$ & Nilai & Kategori & Predikat \\
\hline 2013 & 64 & 70 & 91 & $80<\mathrm{TS}<=95$ & A_A & Sehat \\
\hline 2014 & 65,5 & 70 & 93 & $80<$ TS $<=95$ & ALA & Sehat \\
\hline 2015 & 63,5 & 70 & 90 & $80<\mathrm{TS}<=95$ & A.A & Sehat \\
\hline 2016 & 56,9 & 70 & 81 & $80<$ TS $<=95$ & A.A & Sehat \\
\hline 2017 & 64 & 70 & 91 & $80<\mathrm{TS}<=95$ & A.A & Sehat \\
\hline
\end{tabular}


Berdasarkan penelitian diatas, pada tahun 2013 dengan total bobot skor 91 pada PT. Gas Negara, Tbk dengan nilai $80<$ TS <= 95 dengan menilai berdasarkan tingkat kesehatan BUMN mempunyai predikat sehat karna total bobot yang di dapat PT. Gas Negara hampir menyamai standar rata rata kesehatan perusahaan BUMN dalam perusahaan non Infrastruktur.

Berdasarkan penelitian diatas, pada tahun 2014 dengan total bobot skor 93 pada PT. Gas Negara, Tbk dengan nilai $80<\mathrm{TS}<=95$ dengan menilai berdasarkan tingkat kesehatan BUMN mempunyai predikat sehat karna total bobot yang di dapat PT. Gas Negara hampir menyamai standar rata rata kesehatan perusahaan BUMN dalam perusahaan non Infrastruktur.

Berdasarkan penelitian diatas, pada tahun 2015 dengan total bobot skor 90 pada PT. Gas Negara, Tbk dengan nilai $80<$ TS <= 95 dengan menilai berdasarkan tingkat kesehatan BUMN mempunyai predikat sehat karna total bobot yang di dapat PT. Gas Negara hampir menyamai standar rata rata kesehatan perusahaan BUMN dalam perusahaan non Infrastruktur.

Berdasarkan penelitian diatas, pada tahun 2016 dengan total bobot skor 81 pada PT. Gas Negara, Tbk dengan nilai $80<$ TS <= 95 dengan menilai berdasarkan tingkat kesehatan BUMN mempunyai predikat sehat karna total bobot yang di dapat PT. Gas Negara hampir menyamai standar rata rata kesehatan perusahaan BUMN dalam perusahaan non Infrastruktur.

Berdasarkan penelitian diatas, pada tahun 2017 dengan total bobot skor 91 pada PT. Gas Negara, Tbk dengan nilai $80<$ TS <= 95 dengan menilai berdasarkan tingkat kesehatan BUMN mempunyai predikat sehat karna total bobot yang di dapat PT. Gas Negara hampir menyamai standar rata rata kesehatan perusahaan BUMN dalam perusahaan non Infrastruktur.

\section{G. Kesimpulan dan Saran}

\section{1) Kesimpulan}

1. Hasil analisa Likuiditas laporan keuangan PT. Gas Negara Tbk berdasarkan Keputusan Menteri BUMN No: KEP-100/MBU/2002 mempunyai rata rata dalam indikator Cash Ratio periode 2013 sampai 2017 yaitu sebesar 171\%. Dan dalam indikator Current Ratio periode 2013 sampai 2017 yaitu sebesar $255 \%$.

2. Hasil analisa Profitabilitas laporan keuangan PT. Gas Negara Tbk berdasarkan Keputusan Menteri BUMN No: KEP-100/MBU/2002 mempunyai rata rata dalam indikator ROE periode 2013 sampai 2017 yaitu sebesar 25\%. Dan dalam indikator $R O /$ periode 2013 sampai 2017 sebesar 346\%.

3. Hasil analisis Rasio Aktivitas berdasarkan Keputusan Menteri BUMN No: KEP100/MBU/2002 untuk indikator Collection Periods PT. Gas Negara periode 2013 sampai 2017 mendapatkan 26 hari. Dan dalam indikator Perputaran Persediaan yang sama yg memiliki 34 hari. Dalam indikator TATO (Total Asset Turn Over) periode 2013 sampai 2017 mendapatkan 166\%.

4. Analisis Rasio Solvabilitas berdasarkan Keputusan Menteri BUMN No:KEP100/MBU/2002 untuk indikator Total Modal Sendiri Terhadap Total Asset (TMS Terhadap TA) periode 2013 sampai 2017 yaitu sebesar 162\%.

5. Kinerja keuangan PT. Gas Negara Tbk secara keseluruhan disimpulkan bahwa berdasarkan hasil perhitungan rasio likuiditas, rasio profitabilias, rasio ekuitas dan rasio solvabilitas berdasarkan Keputusan Menteri BUMN No: KEP100/MBU/2002 periode 2013 sampai 2017 dinyatakan sehat. Karena dari 
seluruh rasio keuangan PT. Gas Negara Tbk, semua mencapai standar tingkat kesehatan perusahaan non infrastruktur.

\section{2) Saran}

1. Bagi Pihak Perusahaan (internal)

Penelitian yang dilakukan pada laporan keuangan PT. Gas Negara Tbk periode 2013 sampai 2017 adalah sehat. Hal ini dapat diketahui setelah rata - rata rasio keuangan PT. Gas Negara Tbk. Saran yang penulis dapat berikan untuk kemajuan perusahaan adalah sebagai berikut:

a. Perusahaan diharapkan dapat menambah asset dari modal sendiri tanpa harus hutang dan sedapat mungkin mengurangi hutang tanpa harus mengurangi aktiva dengan harapan perusahaan berada posisi likuid.

b. Perusahaan diharapkan mengembangkan produk secara berkeseimbangan sehigga dapat menciptakan produk yang lebih memiliki keunggulan kempetitif dan dapat menyesuaikan terhadap perubahan yang terjadi, terutama kebutuhan pelanggan.

c. Perusahaan harus lebih efektif dan efisien lagi dalam mengelola aktiva yang dimilikinya. Membuat sistem yang bisa i pantau agar tercapainya tujuan - tujuan perusahaan dengan cara efektif dan efisien.

2. Bagi peneliti lain

a. Meneliti perusahaan yang sudah lebih dari 10 tahun sehingga dapat diketahui tren dari laporan keuangan perusahaan tersebut.

b. Lakukanlah perbandingan dengan perusahaan lain yang sejenis dalam periode yang sama, agar dapat diketahui mana perusahaan yang memiliki kinerja keuangan yang terbaik.

c. Perbanyak membaca kajian pustaka berkaitan dengan rasio keuangan agar analisa yang dilakukan tepat tidak salah kaprah.

3. Bagi pemegang saham dan investor

Memberi kesempatan dan dukungan bagi manajemen untuk terus berkembang sehingga memberikan peluang bisnis yang lebih baik sehingga membawa perusahaan kepada peringkat yang lebih baik.

4. Bagi calon investor

Menjadikan penelitian ini sebagai bahan pertimbangan dalam mengambil keputusan investasi yang akan dilakukan terhadap perusahaan yang akan dipilih. 


\section{H. Daftar Pustaka}

Arief Sugiono. 2009. Manajemen Keuangan. Jakarta: Penerbit PT. Gramedia Widiasarana Indonesia.

Dermawan, D. (2012). “Pendidikan Teknologi Informasi dan Komunikasi".Bandung. PT Remaja Rosdakarya.

Ermayanti, Dewi (2009). Kinerja Keuangan Perusahaan. Harian Kompas, 15 Oktober 2009 diakses dari http://dwiermayanti.wordpress.com/feed/html pada tanggal 5 November 2015

Fahmi, I (2010) Pengantar Manajemen Keuangan. Malaysia: Alfabeta. (2013. Analisis Laporan Keuangan. Bandung: Alfabeta.

Hasibuan, Malayu. 2012. "Manajemen Sumber Daya Manusia”. Jakarta: PT Bumi Aksara.

Harahap, Soyan Syafri. 2015. Analisis Kritis atas Laporan Keuangan. Edisi 1-10 Jakarta: Rajawali Pers.

Ikatan Akuntan Indonesia (IAI). 2016. Standar Akuntansi Keuangan revisi 2016. Salemba Empat. Jakarta.

Jumingan. 2011. Analisis Laporan Keuangan. Jakarta: Bumi Aksara.

Kasmir. 2015. Analisis Laporan Keuangan. Edisi 1-8. Jakarta: Rajawali Pers.

Munawir, S. 2010. Analisis Laporan Keuangan Edisi keempat. Cetakan Kelima Belas. Yogyakarta: Liberty.

Munawir, 2008. Analisis Laporan Keuangan. Edisi IV. Yogyakarta: Liberty

Mullins, Walker (2010) . Analisis Laporan Keuangan. Mc. Graw Hill

Robbins, P. Stephen dan Timothy A. Judge 2012. Perilaku Organisasi. Salemba Empat. Jakarta.

Sahara, Y. (2015). Skripsi. Analisis Rasio Likuiditas dan Profitabilitas Untuk Mengukur Kinerja Keuangan PT. Astra Internasional.

Sunardi, N., Hamid, A. A., Lativa, A. K., \& Tulus, N. (2018). Determinant Of Cost Efficiency And It's Implications For Companies Performance Incorporated In The Lq. 45 Index Listing In Idx For The Period of 2011-2016. International Journal of Applied Business and Economic Research, 16(1).

Sunardi, N. (2017). Determinan Kebijakan Utang Serta Implikasinya terhadap Kinerja Perusahaan (Perusahaan yang tergabung dalam indeks LQ. 45 yang terdaftar di Bursa Efek Indonesia Tahun 2011-2015). Jurnal Sekuritas, 1(1).

Sunardi, N. (2019). Determinan Intelectual Capital dengan Pendekatan iB-VAIC ${ }^{\text {TM }}$ Terhadap Efisiensi Biaya Implikasinya Pada Profitabilitas Perbankan Syariah di Indonesia. JIMF (Jurnal IImiah Manajemen Forkamma), 1(1).

Sunardi, N. (2018). Analisis Du Pont System Dengan Time Series Approach (Tsa) Dan Cross Sectional Approach (Csa) Dalam Penilaian Kinerja Keuangan Perusahaan (Studi Pada Industri Konstruksi (BUMN) di Indonesia Yang Listing di BEI Tahun 2013-2017). Jurnal Sekuritas (Saham, Ekonomi, Keuangan dan Investasi), 1(4).

Sunardi, N. (2019, January). Relevansi Struktur Kepemilikan Tentang Profitabilitas Dan Nilai Perusahaan (Studi pada Industri Manufaktur yang Terdaftar di Bursa Efek Indonesia Periode 2010-2017). In Proceedings (Vol. 1, No. 1).

Sunardi, N., \& Sasmita, A. S. (2019). Pengaruh Likuiditas, Leverage Dan Growth Terhadap Kinerja Industri Makanan Dan Minuman Yang Tercatat Di Indonesia Stock Exchange Selama Periode Tahun 2011-2015. Jurnal Sekuritas (Saham, Ekonomi, Keuangan dan Investasi), 2(2), 81-97. 